\title{
MEMBENTUK KARAKTER ANAK MELALUI HABITUASI DONGENG PADA PEMBELAJARAN DI SEKOLAH DASAR
}

\author{
Ni Putu Candra Prastya Dewi \\ Sekolah Tinggi Agama Hindu Negeri Mpu Kuturan \\ Pendidikan.dasar500@gmail.com \\ Ida Bagus Putrayasa \\ Universitas Pendidikan Ganesha \\ ib.putrayasa@undiksha.ac.id \\ I Nyoman Sudiana \\ Universitas Pendidikan Ganesha \\ nyoman.sudiana@undiksha.ac.id
}

\begin{abstract}
The purpose of this study is to shape the character of children through habituation of fairy tales in learning in elementary schools. This type of research is descriptive qualitative research. Methods of data collection is done by interview and literature study. The subjects of this study were elementary school teachers totaling 10 people, which were taken with a sampling technique, namely purposive sampling. Data analysis in this study consisted of stages of data collection, data reduction, data presentation, and conclusion/verification. The results showed that storytelling is an effective way that teachers can do to grow the character of students. By linking learning materials with fairy tales students become interested in learning. The characters and storylines in fairy tales provide moral messages that can be imitated by students. The characters that can be instilled in fairy tales are manners, discipline, moral values, spirituality, religion, responsibility, love for the homeland, never give up.
\end{abstract}

Keywords: fairy tales, character building, elementary school

\begin{abstract}
ABSTRAK
Tujuan penelitian ini yaitu untuk membentuk karakter anak melalui habituasi dongeng pada pembelajaran di sekolah dasar. Jenis penelitian ini adalah penelitian deskriptif kualitatif. Metode pengumpulan data dilakukan dengan wawancara dan studi kepustakaan. Subyek penelitian ini adalah guru sekolah dasar berjumlah 10 orang, yang diambil dengan teknik pengambilan sampel yaitu purposive sampling. Analisis data dalam penelitian ini terdiri atas tahapan pengumpulan data, reduksi data, penyajian data, serta simpulan/verifikasi. Hasil penelitian menunjukkan bahwa mendongeng merupakan cara efektif yang dapat dilakukan guru untuk menumbuhkan karakter siswa. Dengan mengaitkan materi pembelajaran dengan dongeng siswa menjadi tertarik untuk belajar. Karakter tokoh serta alur cerita dalam dongeng memberikan pesan moral yang dapat ditiru peserta didik. Adapun karakter yang dapat ditanamkan dalam dongeng adalah sopan santun, kedisiplinan, nilai-nilai moral, spiritual, agama, tanggung jawab, cinta tanah air, pantang menyerah.
\end{abstract}

Kata Kunci: dongeng, pembentukan karakter, sekolah dasar

\section{PENDAHULUAN}

Pada era globalisasi ini, kita ketahui bersama perkembangan teknologi begitu pesat. Hal ini menghilangkan sekat-sekat antar daerah sehingga memudahkan masukknya budaya asing ke Indonesia. Namun tidak semua budaya asing tersebut sesuai dengan budaya Indonesia. Hal inilah yang harus diwaspadai oleh masyarakat Indonesia, utamanya generasi muda agar tidak mudah terjerumus dalam pengaruh negatif globalisasi. 
Menurut Lickona (2013) ada 10 indikasi gejala penurunan moral yang perlu mendapatkan perhatian agar berubah ke arah yang lebih baik; 1) Kekerasan dan tindakan anarki, 2) Pencurian, 3) Tindakan Curang, 4) Pengabaian terhadap aturan yang berlaku, 5) Tawuran antar siswa, 6) Ketidaktoleran, 7) Penggunaan bahasa yang tidak baik, 8) Kematangan seksual yang terlalu dini dan penyimpangannya, 9) Sikap perusakan diri, 10) Penyalahgunaan Narkoba. Sulistyowati (2012) menyebutkan bahwa dua faktor yang menjadi permasalahan di Indonesia. Faktor pertama adalah berubahnya nilai-nilai kesopanan dan tata krama bangsa Indonesia dibanding dengan keadaan di masa lalu. Sementara faktor kedua adalah terkikisnya pengertian nilai-nilai bangsa yang luhur yang ada di masyarakat Indonesia pada jaman dulu.

Permasalahan mengenai degradasi moral sangat dipengaruhi oleh kemajuan alat komunikasi smartphone sudah lazim dimiliki oleh siswa sekolah dasar. Penggunaan smartphone oleh siswa sekolah dasar memberikan dampak positif, namun terdapat sisi negatif. Menurut Munir (2008), sisi positif dari adanya perkembangan teknologi tersebut pun menjadikan mobilitas yang dilakukan oleh manusia lebih mudah dan lebih canggih dalam segala hal. Dampak negatif dari perkembangan teknologi adalah kemerosotan moral/degradasi moral. Degradasi moral dari pengaruh internet sangat memungkinkan karena pintu akses konten internet tanpa batasan usia membuat dampak negatif bagi anak-anak.

Degradasi moral siswa di sekolah dasar paling mengkhawatirkan yaitu 68 persen siswa sekolah dasar sudah aktif mengakses konten porno (Zubaidah, 2013). Selain itu, data Pusat Pengendalian Gangguan Sosial DKI Jakarta menyebutkan pelajar SD, SMP, dan SMA yang terlibat tawuran mencapai 0,08\% atau sekitar 1.318 siswa dari total 1.647 .835 siswa DKI Jakarta. Bahkan, 26 siswa diantaranya meninggal dunia (Mashlihuddin, 2021). Persoalan remaja saat ini tidak sampai disitu saja, akhir-akhir ini banyak bermunculan kasus tentang siswa yang melawan gurunya. Bahkan sampai ada yang tega menganiaya gurunya sendiri. Seperti kejadian di SD Negeri 1 Balongsari, Surabaya, siswa yang ditegur karena tidak menggunakan atribut kartini dalam rangka Hari Kartini sesuai yang diinstruksikan. Siswa tersebut justru memakai pakaian ala anak jalanan, menggunakan celana sobek lengkap dengan rantai. Namun Ketika kepala sekolah mendekat justru siswa tersebut menendang kepala sekolah hingga tangannya patah (Rasni, 2019). Hal ini tentunya sudah kelewat batas, tidak ada lagi rasa hormat dan etika yang tertanam pada diri siswa tersebut.

Selain permasalahan tersebut, di zaman modern ini, aktivitas mendongeng sudah jarang dilakukan orangtua terhadap anak-anak mereka. Survei yang diadakan Disney di Inggris membuktikan bahwa hanya sepertiga orangtua di Inggris yang masih sempat membacakan cerita pada anak sebelum tidur. Survei tersebut diikuti oleh 1.000 orangtua dan kakek-nenek yang memiliki anak atau cucu berusia di bawah enam tahun. Sebagian orangtua mengatakan bahwa mereka tidak memiliki cukup waktu untuk mendongeng bagi anakanak mereka. Hampir sepertiga orangtua yang menjadi responden mengaku terlalu lelah untuk bercerita, terlebih ketika mereka terlambat pulang kantor dan harus melakukan pekerjaan rumah lainnya. Dari survei Disney tersebut juga terungkap, di era digital seperti sekarang ini, dua pertiga dari orangtua dan kakek-nenek merasa bahwa teknologi modern sudah menghilangkan tradisi mendongeng (Habsari, 2017). Jika kejadian ini terus berlanjut, maka anak-anak akan jauh dari akhlak, moral, dan etika baik.

Berdasarkan permasalahan tersebut, penanaman karakter sangatlah diperlukan. Penanaman karakter tersebut sebaiknya sedini mungkin sehingga ketika menjadi dewasa, anak terbiasa menyaring pengaruh kemajuan teknologi yang sesuai dengan budaya di Indonesia. Pembentukan karakter anak memang tidak dapat dilakukan dalam waktu yang singkat 
karena membutuhkan proses panjang dalam waktu yang lama. Hal tersebut juga dilakukan secara terus-menerus dengan menggunakan metode yang tepat dan efektif.

Untuk membentuk ahlak dan moral anak, sebaiknya dimulai sejak dini. Hal ini sesuai dengan pendapat Suyadi (dalam Subiyantoro, 2012:2) menjelaskan bahwa menurut para psikolog, masa kanak-kanak adalah masa yang penuh dengan imajinasi. Anak mempunyai daya imajinasi yang lebih beragam dari pada orang dewasa. Terlebih lagi ketika anak-anak bermain peran, yaitu memerankan tokoh dari sebuah cerita, maka majinasinya akan menghidupkan daya fantasinya sehingga ia seolah-olah benar-benar menjadi sosok yang diperankannya tersebut. Oleh karena itu, pembelajaran yang memadukan dongeng dapat mengasah imajinasi anak serta mampu menyampaikan pesan moral untuk ditiru anak nantinya.

Dongeng adalah salah satu alternatif yang tepat yang mampu meningkatkan imajinasi anak sekaligus memupuk karakter anak. Menurut Dudung (2015), dongeng adalah bentuk sastra lama yang bercerita tentang kejadian luar biasa yang penuh khayalan (fiksi) dan tidak benar-benar terjadi. Selain itu, Kamisa (dalam Rosidah dan Rusminati, 2017) menjelaskan bahwa pengertian dongeng adalah cerita yang dituturkan atau dituliskan yang bersifat hiburan dan biasanya tidak benar-benar terjadi dalam kehidupan. Dongeng merupakan suatu bentuk karya sastra yang ceritanya tidak benar-benar tejadi atau fiktif yang bersifat menghibur dan terdapat ajaran moral yang terkandung dalam cerita dongeng tersebut. Berdasarkan pengertian-pengertian tersebut, maka dapat disimpulkan bahwa dongeng adalah cerita fiktif yang bertujuan untuk menghibur dan mengandung nilai-nilai budi pekerti di dalamnya.

Dongeng dapat dibagi menjadi tujuh jenis, yaitu mitos, sage, fabel, legenda, cerita lucu, cerita pelipur lara, dan perumpamaan. Jenis-jenis dongeng antara lain (1) mitos: bentuk dongeng yang menceritakan hal-hal magis seperti cerita tentang dewa-dewa, peri atau Tuhan; (2) sage: dongeng kepahlawanan, keberanian, atau sihir seperti sihir dongeng Gajah Mada; (3) fabel: dongeng tentang binatang yang dapat berbicara atau berperilaku seperti manusia; (4) legenda: bentuk dongeng yang menceritakan tentang sebuah peristiwa tentang asal-usul suatu benda atau tempat; (5) cerita jenaka: cerita yang berkembang di masyarakat dan dapat membangkitkan tawa; (6) cerita pelipur lara: biasanya berbentuk narasi yang bertujuan untuk menghibur tamu di pesta dan kisah yang diceritakan oleh seorang ahli; dan (7) cerita perumpamaan: bentuk dongeng yang mengandung kiasan, contohnya adalah didaktik dari Haji Pelit. Cerita tersebut tumbuh dan berkembang di daerah dan dinamakan cerita lokal (Dudung, 2015).

Berbagai jenis dongeng tersebut memiliki nilai-nilai moral yang dapat dimanfaatkan sebagai sumber pembentukan karakter anak. Hanya saja, pendidik perlu memilihkan dongeng yang sesuai dengan usia dan perkembangan psikologi serta minat anak. Pendidikan karakter secara terintegrasi di dalam proses pembelajaran adalah pengenalan nilai-nilai, memfasilitasi diperolehnya kesadaran akan pentingnya nilai-nilai, dan penginternalisasian nilai-nilai ke dalam tingkah laku peserta didik sehari-hari melalui proses pembelajaran, baik yang berlangsung di dalam maupun di luar kelas pada semua mata pelajaran, selain untuk menjadikan peserta didik menguasai materi yang ditargetkan, juga dirancang dan dilakukan untuk menjadikan peserta didik mengenal, menyadari/peduli, dan meng-internalisasi nilainilai dan menjadikannya perilaku (Jamilah, 2017).

Dongeng yang disampaikan guru dalam kondisi dan suasana yang tepat, mampu membawa imajinasi anak untuk menilai sikap bahkan mengembangkan karakter tokoh pada dongeng. Munculnya tokoh dengan sifat protagonis mampu memunculkan idola pada setiap anak sehingga wawasan dan pesan moral dalam dongeng akan diterima oleh anak. 
Keberhasilan dongeng dalam membentuk karakter anak sejalan dengan penellitian yang dilakukan oleh Sufitri dan Setyowani (2019) yang hasilnya menunjukkan bahwa dongeng sebagai media dalam penerapan karakter sangatlah efektif untuk diterapkkan kepada anak sekolah dasar dan perlunya pembiasaan serta contoh yang baik untuk menumbuhkan karakter dari anak. Sejalan dengan hal tersebut, Agustina dan Arifin (2021) juga melakukan penelitian yang hasilnya menunjukkan bahwa dari 8 dongeng yang dianalisis dalam buku "Dongeng Terpopuler Sepanjang Masa" karya Ungu Lianza ditemukan bahwa bentuk nilai pendidikan karakter yang ditemukan berjumlah 6, yaitu (1) Rasa Ingin Tahu, (2) Bersahabat/Komunikasi, (3) Cinta Damai, (4) Peduli Sosial, (5) Kerja Keras, (6) Toleransi.

Berdasarkan latar belakang di atas serta dukungan dari penelitian yang relevan, maka peneliti tertarik untuk melakukan penelitian yang berjudul "Membentuk Karakter Anak Melalui Habituasi Dongeng pada Pembelajaran di Sekolah Dasar". Tujuan penelitian ini adalah mengetahui pembentukan karakter siswa sekolah dasar melalui habituasi dongeng pada pembelajaran.

\section{METODE PENELITIAN}

Jenis penelitian ini adalah penelitian deskriptif kualitatif. Penelitian deskriptif kualitatif yaitu penelitian tentang data yang dikumpulkan dan dinyatakan dalam bentuk kata-kata dan gambar, kata-kata disusun dalam kalimat. Metode pengumpulan data dilakukan dengan wawancara dan studi kepustakaan. Wawancara dilakukan dengan memberikan pertanyaan yang harus diisi melalui google form. Adapun pertanyaan tersebut yaitu 1) apakah dongeng dapat membentuk karakter anak di sekolah?; 2) jenis dongeng yang baik untuk diberikan pada siswa sekolah dasar; 3) cara penerapan dongeng pada pembelajaran di sekolah; 4) cara penerapan dongeng di luar pembelajaran di kelas; 5) karakter yang dibentuk melalui pembelajaran yang mengaitkan dongeng. Sedangkan studi kepustakaan dilakukan dengan mengumpulkan berbagai sumber atau referensi yang berkaitan dengan penelitian. Subyek penelitian ini adalah guru sekolah dasar berjumlah 10 orang, yang diambil dengan teknik pengambilan sampel yaitu purposive sampling. Teknik ini dilakukan dengan memilih 10 orang guru sekolah dasar yang diambil dari 10 Sekolah yang ada di Kecamatan Buleleng. Pertimbangan ini didasarkan pada perwakilan guru yang diambil dari 10 sekolah berbeda yang mampu mewakili guru sekolah dasar di Kecamatan Buleleng untuk memberikan keterangan mengenai permasalahan yang ditemukan. Analisis data dalam penelitian ini terdiri atas tahapan pengumpulan data, reduksi data, penyajian data, serta simpulan/verifikasi. Penyajian data dilakukan dengan menginterpretasikan hasil dari wawancara yang dilakukan pada 10 orang guru sekolah dasar di Kecamatan Buleleng. Kemudian mengaitkannya dengan teori yang mendukung serta penelitian yang relevan, untuk kemudian ditarik kesimpulan yang tepat.

\section{HASIL DAN PEMBAHASAN}

\section{Hasil}

Karakter siswa sekolah dasar dapat dibentuk dengan berbagai cara, salah satunya dengan mengaitkan pembelajaran dengan dongeng. Hal ini disebabkan karena dongeng dapat membawa siswa pada imajinasi yang membuatnya tertarik untuk belajar. Untuk mengetahui keefektifan dongeng sebagai media yang digunakan untuk menumbuhkan karakter anak dilakukan dengan mewawancarai 10 orang guru sekolah dasar. Adapun beberapa pertanyaan yang diberikan yaitu : 1) apakah dongeng dapat membentuk karakter anak di sekolah?; 2) jenis dongeng yang baik untuk diberikan pada siswa sekolah dasar; 3) cara penerapan dongeng pada 
pembelajaran di sekolah; 4) cara penerapan dongeng di luar pembelajaran di kelas; 5) karakter yang dibentuk melalui pembelajaran yang mengaitkan dongeng.

Menurut beberapa responden yang diwawancarai mengenai apakah dongeng dapat membentuk karakter anak di sekolah?, diperoleh hasil sebagai berikut. 1)Bisa, karena dongeng mengandung nilai moral dan sosial yang berguna untuk membentuk karakter anak; 2) Bisa karena dongeng dapat digunakan sebagai media untuk mendidik serta membentuk karakter positif pada anak oleh orang tua maupun guru. Dengan kegiatan positif yang menyenangkan seperti kegiatan mendongeng, kegiatan menumbuhkan karakter anak dapat dilakukan sejak dini baik di lingkungan keluarga maupun sekolah; 3) Menurut perspektif saya tentu karena anakanak tingkat sekolah dasar merupakan pondasi awal penanaman/pembentukan karakter anak, dengan media dongeng siswa akan merasa tertarik dan terbawa suasana, sehingga dengan cerita dongeng siswa dapat dipengaruhi penanaman karakter dari masing-masing tokoh/alur di dalam dongeng tersebut; 4) karena dari mendengarkan dongeng anak dapat mengetahui hal baik dan buruk, dari hal baik dan buruk itu lah anak akan mengadaptasi dan mengimplementasikannya ke dalam dirinya; 5) Iya, karena anak SD dengan membaca dongeng atau menonton dongeng anak akan mengikuti karakter dari dongeng tersebut akan ditirukan. Berdasarkan hasil wawancara tersebut diketahui bahwa dongeng dapat membentuk karakter anak karena pada dongeng terdapat pesan moral yang dapat diambil baik dari tokoh, maupun dari alur ceritanya, sehingga dapat diimplementasikan dalam kehidupan sehari-hari. Ketertarikan anak pada dongeng juga membuat pesan moral itu mudah dipahami dan diikuti oleh anak.

Sedangkan pertanyaan kedua mengenai jenis dongeng yang baik untuk diberikan pada siswa sekolah dasar diperoleh hasil sebagai berikut. 1) Biasanya dongeng yg biasa diceritakan kpd anak SD adalah dongeng jenis Fabel yg dimana dongeng ini bercerita tentang binatang yang dapat berbicara atau berperilaku seperti manusia. Contohnya sprti dongeng si kancil anak nakal; 2) Dongeng malinkundang, atau batu menangis; 3) Menurut saya dongeng yang baik untuk diberkan kepada anak sekolah dasar adalah salah satunya dongeng budaya, seeperti contoh dongeng legenda legenda yang ada di daerah daerah; 4) Dongeng Bawang Putih dan Bawang Merah; 5) Dongeng fabel(binatang), jenaka(lucu), hikayat, legenda, mite/mitos; 6) Dongeng yang memiliki pesan moral. Contohnya Si Kancil Yang Cerdik, Gajah Yang Pelupa. Berdasarkan hasil wawancara tersebut, ada berbagai jenis dongeng yang dapat diberikan kepada siswa sekolah dasar sesuai dengan jenisnya. Ada jenis fabel (binantang) contohnya si kancil dan buaya, jenaka (lucu) contoh abu nawas, hikayat contohnya sri rama mencari dewi sita, legenda contohnya legenda danau toba, mite/mitos contohnya asal mula banyuwangi. Kesemua dongeng tersebut memiliki fungsinya tersendiri dan tentunya menyampaikan pesan moral sehingga dapat dipelajari oleh anak.

Pertanyaan ketiga mengenai cara menerapkan dongeng dalam pembelajaran di sekolah diperoleh hasil sebagai berikut. 1) Cara menerapkan dongeng dalam pembelajaran di sekolah yaitu dengan cara mengaitkan materi pelajaran dengan dongeng, kemudian sebelum belajar guru bisa meminta siswa membaca dongeng atau meminta siswa membuat kliping tentang dongeng; 2) Menayangkan video dongeng tersebut; 3) Mengisi pada sisa waktu pembelajaran, atau di awal pembelajaran sebagai bentuk sarana literasi; 4) Menurut saya cara menerapkan dongeng di sekolah adalah dengan memmberikan anak media media literasi seperti gambar ataupun video; 5) Dengan cara mengaitkan dongeng dengan kehidupan sehari-hari dengan menampilkan video dongeng tersebut; 6) Dengan menyelipkannya pada materi pelajaran. Berdasarkan hasil wawancara tersebut, diketahui bahwa dongeng dapat diterapkan pada pembelajaran di sekolah dengan berbagai cara salah satunya mengaitkan materi dengan 
dongeng baik dengan memberikan video, membaca maupun membuat kliping mengenai dongeng yang diberikan sehingga siswa lebih mudah memahami materi pembelajaran.

Pertanyaan keempat mengenai cara mengajarkan dongeng kepada siswa selain pembelajaran dikelas, diperoleh hasil sebagai berikut. 1) mengajak anak-anak membaca dongeng di perpusatakan ketika jam istirahat, atau mengadakan lomba membaca dongeng; 2) Menggunakan Kartu Dongeng, orangtua bisa menggunakan kartu dongeng atau yang dikenal juga sebagai buku cerita, mengkreasikan barang-barang sederhana, menggunakan video dongeng dan Mendongeng menggunakan buku. 3) mengadakan hari wajib literasi dimana semua murid mengunjungi perpustakaan untuk mencari dongeng kesukaannya dan membacanya di tempat yang ia sukai di lingkungan sekolah; 4) membaca dongeng anak di rumah saat tidur; 5) membuatkan video dongeng agar lebih menarik dan bisa ditonton berulangulang oleh anak. Berdasarkan hasil wawancara tersebut, diketahui bahwa dongeng selain diterapkan dalam pembelajaran di kelas, bisa juga di luar kelas seperti mengajak siswa mengunjungi perpustakaan untuk membaca dongeng ataupun memutarkan video dongeng di luar jam pelajaran. Mengikutsertaan anak dalam lomba dongeng, Selain itu bisa juga dengan melibatkan orang tua anak dengan meminta membacakan dongeng sebelum tidur sehingga karakter anak dapat dibentuk melalui pembacaan dongeng tersebut.

Pertanyaan kelima mengenai karakter yang dapat dibentuk melalui pembelajaran yang mengaitkan dongeng adalah sebagai berikut. 1) Karakter yang dapat dibentuk melalui pembelajaran yang mengaitkan dongeng yaitu imajinasi, daya kritis anak, kejujuran, toleransi, jujur, rendah hati; 2) Kejujuran, mengatasi masalah emosi, dan sopan santun; 3) Berbuat yang baik, berbicara yang baik, berpikir yang baik; 4) Karakter displin, etika dan sopan santun; 5) Percaya diri, rendah hati, kerja keras, pantang menyerah; 6) Semua karakter terbentuk karena banyak sekali pembelajaran yang dijadikan patokan oleh anak bahkan dongeng bawang teken kesune masih melekat dan saya ingat sampai sekarang. Berdasarkan hasil wawancara tersebut, diketahui bahwa berbagai karakter dapat dibentuk dari habituasi dongeng pada siswa sekolah dasar, di antaranya jujur, toleransi, rendah hati, sopan santun, disiplin, kerja keras, percaya diri, pantang menyerah, komunikatif, demokratis, cinta tanah air. Karakter tersebut dapat dipelajari melalui alur cerita yang terdapat dalam dongeng. Dengan anak memahami karakter atau alur cerita dongeng, maka karakter tersebut akan tertanam dalam diri anak.

\section{Pembahasan}

Pendidikan karakter salah satu dari kemampuan soft skill, yakni proses tuntunan kepada anak didik agar menjadi manusia seutuhnya yang berkarakter dalam dimensi hati, pikir, raga serta rasa dan karsa. Karakter individu dimaknai sebagai hasil keterpaduan antar olah hati, olah pikir, olah raga dan perpaduan olah rasa dan karsa. Pendidikan karakter berbasis nilai-nilai budi pekerti yang mendasari prilaku, pola tindak, dan sikap peserta didik (Cahyani, 2012). Pada intinya, pendidikan karakter akan membentuk kepribadian seseorang yang di dalamnya terdiri atas tiga komponen, yakni moral knowing, moral feeling, dan moral action (Martono, 2012). Hal ini diperlukan agar peserta didik mampu memahami, merasakan, dan melaksanakan nilai-nilai kebaikan.

Pendidikan karakter dilakukan melalui pendidikan formal, informal dan non formal. Pada jalur pendidikan formal maka pendidikan yang paling dasar adalah sekolah dasar sehingga pendidikan karakter secara formal juga dimulai di sini. Pendidikan karakter yang kuat dan kokoh merupakan hal yang penting dan harus ditanamkan sejak dini agar anak bangsa menjadi pribadi yang unggul seperti yang diharapkan dalam tujuan Pendidkan Nasional dan dapat memperkokoh bangsa dari pengaruh negatif globalisasi. 
Upaya untuk membantu perkembangan pribadi dan potensi anak usia dini dalam menanamkan pendidikan karakter, dapat melalui sebuah media lisan yakni dengan media dongeng atau bercerita serta dibarengi dengan media bermain untuk anak usia dini. Menurut beberapa survey oleh ahli anak mengatakan bahwa dalam masa perkembangannya anak paling banyak belajar melalui mendengar dan melihat kemudian mempraktekkannya. Oleh karena itu, perlu dikembangkan pendidikan berbasis budaya lokal yang positif. Salah satunya caranya adalah dengan mengenalkan dan membiasakan anak untuk mendengarkan, membaca cerita-cerita rakyat yang ada di daerahnya. Menurut pandangan Sulistyorini (dalam Fitroh, 2015) yang mengatakan bahwa penyadaran nilai moral anak sangat tepat jika dilakukan melalui cerita atau dongeng sebab cerita atau dongeng merupakan media efektif untuk menanamkan nilai dan estetika kepada anak. Tujuan dari hal tersebut yakni melalui cerita dongeng juga, anak diajarkan untuk mengambil hikmah, kesimpulan dan pesan moral yang berbudi luhur tanpa merasa digurui, karena sebuah cerita lebih berkesan daripada sebuah nasehat murni atau tutur kata yang secara langsung disampaikan. Cerita yang indah akan masuk dalam jiwa dan membentuk karakter yang indah pula, mendongeng sangat penting diberikan kepada anak-anak baik dirumah maupun di sekolah, sebab melalui dongeng guru atau orang tua bisa menyampaikan pembelajaran kepada anak-anak secara menyenangkan sekaligus membuat anak merasa terhibur.

Berdasarkan hasil wawancara yang dilakukan, dongeng sangat baik diterapkan dan disisipkan pada pembelajaran di sekolah maupun di luar jam pembelajaran karena dapat membentuk berbagai karakter yang dapat dipelajarinya melalui karakter sang tokoh ataupun melalui alur cerita dongeng. Sesuai dengan pendapat Soetantyo (2012) yang menyatakan bahwa dongeng adalah sarana yang efektif untuk memberikan pendidikan nilai-nilai pada anak, karena cara penyampaiannya yang tidak memaksa anak-anak untuk menerimanya. Tokohtokoh dalam cerita dapat memberikan teladan bagi anak-anak. Sifat atau karakter anak adalah mempunyai kecenderungan untuk meniru dan mengidentifikasikan diri dengan tokoh yang dikaguminya.Melalui dongeng, anak akan dengan mudah memahami sifat-sifat, figur-figur, dan perbuatan-perbuatan yang baik dan yang buruk. Strategi pembentukan karakter anak dapat dilakukan dengan pemberian contoh, pembiasaan membaca dongeng, pembiasaan mendengarkan dongeng, dan penciptaan lingkungan baca yang mendukung (Habsari,2017).

Pendapat tersebut didukung oleh pendapat Hendri (2014) mengenai manfaat dongeng di antaranya 1) mengajarkan budi pekerti pada anak; 2) membiasakan budaya membaca; 3) mengembangkan imajinasi. Membacakan dongeng pada anak dapat mengasah kreativitas dan minat anak dalam membaca. Selain itu, anak juga bisa belajar nilai-nilai karakter yang ada dalam cerita. Jika kebiasaan baik seperti ini terus diterapkan, maka akan memberikan manfaat positif bagi tumbuh kembang mental anak, bahkan memberikan pengaruh yang baik bagi kehidupannya di masa depan. Dongeng juga dapat dimanfaatkan sebagai upaya untuk mengasah emosi, menumbuhkan imajinasi serta meningkatkan daya kritis anak. Pada umumnya, dongeng membawa misi yang bernilai positif dan edukatif. Melalui dongeng, emosi anak diharapkan dapat terkendali, imajinasi anak dapat berkembang, dan anak dapat berpikir kritis.

Berbagai nilai moral yang disampaikan dalam cerita dongeng dapat dijadikan pedoman pada anak untuk diterapkan sehingga dapat membentuk karakter anak. Menurut Sulistyarini (2006), dongeng mengandung nilai luhur bangsa, terutama nilai-nilai budi pekerti maupun ajaran moral. Apabila cerita rakyat itu dikaji dari sisi nilai moral, maka dapat dipilah menjadi nilai moral individual, nilai moral sosial, dan nilai moral religi. Adapun nilai-nilai moral 
individual meliputi (1) kepatuhan, (2) keberanian, (3) rela berkorban, (4) jujur, (5) adil dan bijaksana, (6) menghormati dan menghargai, (7) bekerja keras, (8) menepati janji, (9) tahu balas budi, (10) rendah hati, dan (12) hati-hati dalam bertindak. Nilai-nilai moral sosial meliputi (1) bekerjasama, (2) suka menolong, (3) kasih sayang, (4) kerukunan, (5) suka memberi nasihat, (6) peduli nasib orang lain, dan (7) suka mendoakan orang lain. Sementara itu, nilai-nilai moral religi meliputi (1) percaya kekuasaan Tuhan, (2) percaya adanya Tuhan, (3) berserah diri kepada Tuhan atau bertawakal, dan (4) memohon ampun kepada Tuhan. Hasil ini didukung oleh pendapat Susanti (2018) juga berpendapat bahwa mendongeng mampu menanamkan sopan santun, kedisiplinan, nilai-nilai moral, spiritual, agama, dan kognitif anak.

Efektifnya penerapan dongeng untuk menumbuhkan karakter anak juga sesuai dengan teori perkembangan kognitif Piaget yang menyatakan bahwa anak usia 7-12 tahun (anak usia sekolah dasar) berada pada tahap operasional konkret, dimana ia belum mampu berfikir abstrak sehingga memerlukan benda konkret untuk memahami sesuatu. Sesuai dengan teori tersebut, dongeng dapat membawa anak pada pembelajaran yang mengaitkan dengan kehidupan nyata anak ataupun mengaitkan dengan lingkungan sekitar anak, sehingga apabila pembelajaran dikaitkan dengan dongeng, anak akan lebih mudah memahaminya. Setelah memahami materi, makai ia dapat pula mengambil sisi positif dari cerita dalam dongeng.

Dongeng dapat diberikan kepada siswa sekolah dasar melalui pembelajaran di dalam kelas maupun di luar kelas. Implementasi dongeng di sekolah dapat dilakukan dengan berbagai cara di antaranya: (1) mewajibkan siswa untuk membaca dongeng sekali setiap minggu yang disediakan perpustakaan sekolah; (2) guru membacakan dongeng yang menarik di depan kelas seminggu sekali, (3) lima menit sebelum pelajaran dimulai, siswa membaca dongeng yang disukainya; (4) siswa mencatat nilai-nilai moral dari dongeng yang telah dibaca; (5) guru menugasi siswa membuat rigkasan mengenai dongeng yang dibacanya seminggu sekali; dan (6) membuat kliping dongeng dari majalah atau koran semiggu sekali.

Pendidikan karaker juga dapat ditanamkan di luar sekolah, misalnya di lingkungan keluarga. Cara yang dapat dilakukan adalah (1) orangtua atau saudara membacakan dongeng sebelum tidur atau di waktu luang; (2) di rumah disediakan bacaaan-bacaan dongeng sehingga bisa menarik minat anak untuk membaca; (3) orangtua mengajukan pertanyaan kepada anak untuk melihat pemahaman dan ingatan anak tentang isi dongeng; dan (4) orangtua mengajak anak ke toko buku dan memberikan kesempatan pada anak untuk membeli buku yang disukainya, termasuk dongeng.

Menumbuhkan karakter anak melalui dongeng juga didukung oleh hasil penelitian yang dilakukan oleh Fitroh dan Sari (2015) yang menunjukkan bahwa dongeng sebagai media dalam penanaman karakter sangatlah efektif untuk diterapkan kepada anak usia dini dan perlunya pembiasaan serta contoh yang baik untuk menumbuhkan karakter dari anak. Selain itu, hasil penelitian Sufitri dan Setyowati (2019) menunjukkan bahwa dongeng sebagai media dalam penerapan karakter sangatlah efektif untuk diterapkkan kepada anak sekolah dasar dan perlunya pembiasaan serta contoh yang baik untuk menumbuhkan karakter dari anak.

Berdasarkan pembahasan tersebut, dapat disimpulkan bahwa dongeng memiliki dampak positif apabila diterapkan dalam pembelajaran. Melalui dongeng siswa sekolah dasar dapat mempelajari karakter melalui peranan tokoh dalam cerita. Nilai-nilai tersebut nantinya dijadikan siswa untuk memilah perilaku baik dan buruk sehingga dapat diterapkan dalam kehidupan sehari-hari. 


\section{PENUTUP}

Berdasarkan hasil dan pembahasan di atas, dapat disimpulkan bahwa mendongeng merupakan cara efektif yang dapat dilakukan guru untuk menumbuhkan karakter siswa. Dengan mengaitkan materi pembelajaran dengan dongeng siswa menjadi tertarik untuk belajar. Karakter tokoh serta alur cerita dalam dongeng memberikan pesan moral yang dapat ditiru peserta didik. Selain itu juga peserta didik mampu membedakan perilaku benar dan perilaku tidak benar melalui peran tokoh tersebut. Habituasi dongeng tidak hanya dapa diterapkan saat pembelajaran di kelas saja. Namun juga di luar jam pembelajaran seperti, mengikutsertakan siswa dalam lomba dongeng, mengajar siswa membaca cerita dongeng di perpustakaan, melakukan pembiasaan membaca dongeng 15 menit sebelum bel pembelajaran dimulai, dan lain sebagainya. Berbagai media dapat digunakan untuk mengajarkan dongeng pada siswa sekolah dasar dinataranya, menggunakan video, kartu bergambar, buku cerita, hingga bermain peran menjadi tokoh dalam dongeng. Adapun karakter yang dapat ditanamkan dalam dongeng adalah sopan santun, kedisiplinan, nilai-nilai moral, spiritual, agama, tanggung jawab, cinta tanah air, pantang menyerah, dan lain sebagainya.

Berdasarkan simpulan tersebut, disarankan kepada guru sekolah dasar agar mengaitkan pembelajaran dengan dongeng agar siswa lebih mudah memahami pembelajaran. Hal ini juga dapat menarik minat belajar siswa. Selain itu disarankan kepada orang tua siswa agar ikut mendukung perkembangan mental dan karakter anak dengan membacakan dongeng pada anak sebelum tidur, sehingga nantinya ia dapat membedakan perilaku baik dan tidak baik untuk diterapkan pada kehidupan nyata.

\section{DAFTAR PUSTAKA}

Agustina, R.L. dan J. Arifin. 2021. Analisis Bentuk Pendidikan Karakter pada Buku Dongeng Anak Terpopuler Sepanjang Masa. Jambura Elementary Education Journal. 2(1), hlm. 152-166.

Cahyani, I. 2012. Pembelajaran menulis berbasis karakter experiental learning. Bandung: Program Studi Pendidikan Dasar SPS UPI.

Fitroh, S.F. dan E.D.N. Sari. 2015. Dongeng Sebagai Media Penanaman Karakter pada Anak Usia Dini. Jurnal PG-PAUD Trunojoyo. Volume 2 Nomor 2, Oktober 2015. Hlm. 76149.

Habsari, Zakia. 2017. Dongeng Sebagai Pembentuk Karakter Anak. BIBLIOTIKA : Jurnal Kajian Perpustakaan dan Informasi. Volume 1 Nomor 1, April 2017. Hlm. 21-29.

Hendri. 2014. Pendidikan Karakter Berbasis Dongeng. Bangung : PT Remaja Rosdakarya.

Jamilah. 2017. Pembentukan Karakter Anak Melalui Pembelajaran Cerita Dongeng Nusantara. Jurnal PTK dan Pendidikan. Volume 3 Nomor 2, Juli-Desember 2017. Hlm. 87-96.

Maslihuddin, Y. 2021. Degradasi Moral Remaja Indonesia. Pelatihan Pembentukan Kepribadian dan Kepemimpinan (P2kk). Tersedia pada https://p2kk.umm.ac. $\mathrm{id} / \mathrm{id} /$ pages/detail/artikel/degradasi-moral-remaja-indonesia.html. Diakses pada 15 Desember 2021.

Munir. 2008. Kurikulum Berbasis Teknologi Informasi dan Komunikasi. Bandung: Alfabeta. 
Rasni. 2019. Detik-detik dan Kronologi Siswa SD Tendang Gurunya hingga Tangan Patah, Gini yang Terjadi Selannjutnya. Tribun-Timur. Tersedia pada https://makassar. tribunnews.com/2019/04/25/detik-detik-kronologi-siswa-sd-tendang-gurunya-hinggatangan-patah-gini-yang-terjadi-selanjutnya?page=all. Diakses pada 15 Desember 2021.

Rosidah, C.T. dan S.H. Rusminati. 2017. Mendongeng sebagai Media Menumbuhkan Karakter dan Nilai Budaya Bangsa pada Siswa Sekolah Dasar. Jurnal Pigur. Volume 1, Nomor 1. Januari 2017. Hlm. 40-50.

Soetantyo, S.P. 2012. Peranan Dongeng dalam Pembentukan Karakter Siswa Sekolah Dasar. Jurnal Pendidikan. Volume 14, Nomor 1. Maret 2013. Hlm. 44-51.

Sulistyowati, E. 2012. Implementasi kurikulum pendidikan karakter. Yogyakarta: PT Citra AjiParama.

Subiyantoro, 2012. Psikolinguistik, Kajian Teoritis Dan Implementasinya. Semarang: UNNES Press.

Sufitri dan R. Setyowati. 2019. Pemanfaatan Dongeng dalam Pembelajaran di Sekolah Dasar sebagai Media untuk Membangun Karakter Siswa. Primary : Jurnal Keilmuan dan Kependidikan Dasar. Volume 11 Nomor 1, Januari-Juni 2019. Hlm. 77-84.

Susanti, Ida. 2018. Siapa Bilang Mendongeng Itu Susah Panduan Mendongeng untuk Guru dan Orang Tua. Bandung : CV Media Cendekia Muslim.

Zubaidah, Neneng. 2013. 68 Persen Siswa SD Sudah Akses Konten Pornografi. Tersedia pada http://nasional.sindonews.com/read/801494/15/68-persen-siswa-sd-su dah-akseskonten-pornografi. Diakses pada 15 Desember 2021. 